Jurnal IImiah Iqra'

2541-2108 [Online] 1693-5705 [Print]

Tersedia online di: http://journal.iain-manado.ac.id/index.php/JII

\title{
Pengembangan Bahan Ajar berbasis Kontekstual untuk Meningkatkan Pemahaman Konsep Sains Dasar Mahasiswa
}

\author{
Rhyan Prayuddy Reksamunandar \\ IAIN Manado, Manado, Indonesia \\ rhyan.reksamunandar@iain-manado.ac.id
}

\begin{abstract}
Abstrak
Penelitian ini bertujuan untuk mengembangkan bahan ajar berbasis kontekstual untuk meningkatkan pemahaman konsep sains dasar mahasiswa. Pengembangan bahan ajar menggunakan pendekatan research and development dengan model uji coba one-group pretes-posttest design. Desain penelitian mengadopsi model yang dikembangkan oleh Plomp yang terdiri dari 4 tahap, yaitu: 1) investigasi awal; 2) desain; 3) realisasi/konstruksi; dan 4) tes, evaluasi, dan revisi. Instrumen penelitian yang digunakan yaitu: 1) lembar angket validasi; 2) lembar angket respon mahasiswa; dan 3) lembar penilaian hasil belajar. Diperoleh hasil bahwa produk pengembangan memenuhi aspek kelayakan $(r=0,84)$ dan aspek kepraktisan $(P=90,5 \%)$ pada kategori sangat baik. Hasil analisis data dengan uji-t pada taraf signifikansi 0,05 diperoleh $\left|t_{\text {statistik }}\right|=26,979$ lebih besar dari $\left|t_{\text {kritis }}\right|=2,043$, sehingga Ho ditolak. Dapat disimpulkan bahwa penggunaan produk pengembangan berpengaruh secara signifikan terhadap pemahaman konsep sains dasar dengan $n$-gain 0,67 pada kategori sedang.

Kata kunci: bahan ajar; sains; kontekstual; pemahaman konsep.
\end{abstract}

\begin{abstract}
This study aims to develop conceptual-based learning material to improve student concept understanding in basic science. The development of learning material uses a research and development approach with a one-group pretest-posttest design trial model. The research design adopted a model developed by Plomp consisting of 4 stages, namely: 1) preliminary investigation; 2) design; 3) realization/construction; and 4) tests, evaluations, and revisions. The research instruments used were: 1) validation questionnaire sheets; 2) student response questionnaire sheets; and 3) learning outcomes assessment sheet. The results show that product development meets the feasibility aspect $(r=0.84)$ and practical aspects $(P=90.5 \%)$ in the very good category. The results of data analysis with t-test at a significance level of 0.05
\end{abstract}


obtained $\left|t_{\text {statistical }}\right|=26,979$ is greater than $\left|t_{\text {critical }}\right|=2,043$, so Ho is rejected. It can be concluded that the use of product development significantly impacts concept understanding in basic science with n-gain of 0.67 in the medium category.

Keywords: learning material, science, contextual, concept understanding.

\section{Pendahuluan}

Sains berperan penting dalam berbagai aspek kehidupan manusia termasuk pendidikan (Grover, 2019). Secara harfiah istilah sains berasal dari Bahasa Latin "scientia" yang berarti pengetahuan. Sains secara umum dicirikan dengan pengumpulan dan pengujian informasi dari berbagai sumber secara sistematis yang bertujuan untuk memberikan penjelasan mengenai alam semesta beserta isinya (Martin, 2009; Clegg, 2019). Sains secara faktual dapat dibagi kedalam dua cabang utama yaitu natural science dan social science (Bunge, 1998). Dalam arti sempit, sains dapat pula diartikan sebagai Ilmu Pengetahuan Alam (IPA) (Hayati, 2017). IPA merupakan ilmu pengetahuan yang berisi tentang fakta, konsep, atau prinsip mengenai gejala alam yang diperoleh melalui proses dan sikap ilmiah (Retno \& Yuhanna, 2016). Di Program Studi Pendidikan Guru Madrasah Ibtidaiyah (PGMI) IAIN Manado, sains diajarkan melalui mata kuliah Konsep Dasar Sains. Sains yang dimaksud adalah natural science atau IPA. Mata kuliah ini bertujuan untuk membekali mahasiswa dengan pengetahuan dan pemahaman mengenai konsepkonsep sains pada tingkat dasar sehingga mahasiswa mampu menyelesaikan berbagai permasalahan yang berkaitan dengan konsep-konsep sains dalam kehidupan sehari-hari dan mampu menerapkannya dalam pembelajaran di kelas.

Pada umumnya peserta didik termasuk mahasiswa beranggapan bahwa sains dan pembelajarannya membosankan dan sulit dipahami (Clegg, 2007; Martin, 2009). Berbagai upaya telah dilakukan oleh banyak peneliti melalui pengembangan model, media, dan metode pembelajaran dengan tujuan untuk perbaikan pembelajaran sains di perguruan tinggi (Insih, 2009; Maulina, dkk., 2016; Retno \& Yuhanna, 2016; Mardiana \& Cahyani, 2018). Proses pembelajaran sains di perguruan tinggi menjadi penting, karena dapat mempengaruhi pengetahuan dan keterampilan mahasiswa untuk mengajarkan konsep dan metode sains secara efektif (Kampourakis, 2017; Fauth, dkk. 2019; Lewis, 2019). Untuk itu dibutuhkan pemahaman konsep-konsep sains dasar yang baik sehingga mahasiswa mampu mengaitkan materi sains dengan kehidupan nyata (Johnson, 2007) dan dapat memberikan pengaruh positif dalam pembelajaran sains di sekolah dasar (Sadler, dkk., 2013; Billah, 2019). Penguasaan konsep yang baik dapat membantu mahasiswa 
dalam menganalisis suatu permasalahan, menginterpretasikan suatu fenomena (Silaban, 2014), dan memiliki pengetahuan untuk menyelesaikan persoalan seharihari dengan baik (Pradana, dkk., 2019).

Salah satu komponen penting dalam pembelajaran terkait sains adalah bahan ajar (Irawati \& Saifuddin, 2018; Billah, 2019). Bahan ajar merupakan seperangkat bahan yang sengaja dibuat dan digunakan dalam pembelajaran (Prastowo, 2015; Widayanti, dkk., 2019). Aspek penting yang perlu diperhatikan dalam penyusunan bahan ajar sains adalah sistematis (Billah, 2019) dan kontekstualitas, yakni materi dalam bahan ajar menggambarkan keadaan nyata dari mahasiswa (Aydin \& Aytekin, 2018). Beberapa penelitian menunjukan bahwa penggunaan bahan ajar berbasis kontekstual yang terkait topik-topik sains dalam proses pembelajaran pada perguruan tinggi dapat meningkatkan pemahaman konsep mahasiswa (Satriawan \& Rosmiati, 2016), keterampilan proses sains (Hayati, 2017), dan hasil belajar mahasiswa (Wulandari, dkk., 2019).

Berdasarkan uraian di atas, pada penelitian ini akan dikembangkan sebuah bahan ajar berupa buku ajar konsep dasar sains berbasis kontekstual untuk meningkatkan pemahaman konsep sains dasar mahasiswa Program Studi PGMI IAIN Manado. Kehadiran buku ajar dapat menunjang proses pembelajaran sains bagi mahasiswa karena sesuai dengan karakteristik belajar mahasiswa yang lebih banyak belajar mandiri daripada tatap muka dengan dosen. Rumusan masalah dalam penelitian ini adalah bagaimana kelayakan, kepraktisan, dan keefektifan produk pengembangan berupa buku ajar konsep dasar sains berbasis kontekstual untuk meningkatkan pemahaman konsep sains dasar mahasiswa.

\section{Kajian Teori}

\section{Bahan Ajar Kontekstual}

Bahan ajar merupakan salah satu bagian dari media pembelajaran yang digunakan dalam melaksanakan kegiatan pembelajaran dan atau untuk perencanaan dan penelaahan (Majid, 2017). Bahan ajar merupakan seperangkat bahan tertulis atau tidak tertulis yang disusun secara sistematis, sehingga tercipta suasana yang mendukung kegiatan pembelajaran (Prastowo, 2015).

Bahan ajar berisikan materi, metode, batasan-batasan dan evaluasi yang dibuat sistematis dan menarik untuk mencapai tujuan yang dharapkan, yaitu 
mencapai kompetensi atau subkompetensi tertentu (Lestari, 2013). Untuk itu, maka ranah kompetensi harus tertuang dalam bahan ajar (Majid, 2017). Suatu bahan ajar yang baik setidaknya memiliki beberapa karakteristik berikut: 1) bahan ajar dapat membuat penggunanya belajar secara mandiri (self instruction); 2) seluruh materi pada bahan ajar merupakan suatu kesatuan yang utuh (self contained); 3) bahan ajar dapat digunakan secara independen tanpa harus bergantung pada bahan ajar lainnya (stand alone); 4) bahan ajar tanggap terhadap perkembangan ilmu dan teknologi (adaptive); dan 5) setiap instruksi dan informasi dalam bahan ajar bersifat membantu dan memudahkan penggunanya (user friendly) (Lestari, 2013). Bahan ajar dapat berbentuk tertulis atau tidak tertulis yang dapat dikelompokkan berdasarkan bentuk, cara kerja, dan sifatnya (Prastowo, 2015).

Salah satu jenis bahan ajar tertulis adalah buku ajar. Buku sebagai bahan ajar didefiniskan sebagai buku dalam bentuk tertulis yang berisi ilmu pengetahuan hasil analisis terhadap kurikulum (Prastowo, 2015; Majid, 2017). Menurut Keputusan Menteri pendidikan Nasional Nomor: 36/D/O/2001 dalam Pasal 5 ayat 9 (a) disebutkan bahwa "Buku ajar adalah buku pegangan untuk suatu mata kuliah yang ditulis dan disusun oleh pakar bidang terkait dan memenuhi kaidah buku teks serta diterbitkan dan disebarluaskan”. Dalam mengembangkan buku ajar, isi buku harus diturunkan dari kompetensi yang tertulis di dalam kurikulum sehingga buku ajar dapat membantu mahasiswa mencapai hasil belajar yang lebih baik. Bahan-bahan dalam buku ajar disusun secara sistematis (Prastowo, 2015; Billah, 2019) dan ditujukan sebagai kelengkapan proses pembelajaran dengan ciri ruang lingkupnya dibatasi oleh kurikulum dan silabus (LKPP Unhas, 2015). Buku ajar yang baik memiliki karakteristik berikut: 1) akurat; 2) sesuai; 3) komunikatif; 4) lengkap dan sitematis; 5) berorientasi pada student centered; 6) berpihak pada ideologi bangsa dan Negara; 7) kaidah bahasa benar; dan 8) terbaca (Akbar, 2013). Unsur-unsur yang setidaknya harus terdapat dalam naskah buku ajar yaitu: 1) sampul depan dan belakang; 2) kata pengantar; 3) daftar isi, daftar tabel, dan daftar gambar; 4) bagian isi yang terbagi dalam bab atau bagian beserta tujuan instruksionalnya; 5) daftar pustaka; 6) glosarium; dan 7) indeks (BSNP, 2006). Setiap buku ajar harus memenuhi kriteria tertentu, yaitu berbagai persyaratan, karakteristik, dan kompetensi minimum yang harus dimiliki buku ajar yang meliputi isi, penyajian, Bahasa, dan kegrafikan (Satriawan \& Rosmiati, 2016; Astiti, 2019).

Selain sistematis, dalam penyusunan bahan ajar perlu memperhatikan aspek kontekstualitas. Kontekstual artinya materi ajar mencerminkan kehidupan sehari- 
hari mahasiswa sebagai pembelajar (Aydin \& Aytekin, 2018). Penerapan pembelajaran kontekstual dapat membantu mahasiwa untuk mewujudkan pembelajaran yang bermakna karena konten yang dipelajari dihubungkan dengan konteks kehidupan nyata (Johnson, 2002). Melalui pembelajaran kontekstual konsep-konsep sains yang abstrak dapat divisualisaikan sehingga mudah dipahami (Astiti, 2019). Penggunaan buku ajar berbasis kontekstual pada perguruaan tinggi berdampak positif terhadap output pembelajaran, dimana pemahaman konsep, keterampilan proses, dan hasil belajar mahasiswa dapat ditingkatkan (Satriawan \& Rosmiati, 2016; Hayati, 2017; Wulandari, dkk., 2019).

Landasan berpikir pendekatan kontekstual adalah konstruktivisme. Dalam konteks ini, pengetahuan dibangun secara bertahap dan diberikan makna melalui pengalaman nyata. Pengetahuan dan keterampilan yang diperoleh merupakan hasil menemukan sendiri (inquiry) dan bukan sekedar mengingat seperangkat fakta (Su'udiah, dkk. 2016). Dari berbagai uraian tersebut, dapat disimpulkan bahwa buku ajar berbasis kontekstual merupakan buku yang disusun secara sitematis, dikembangkan berdasarkan kurikulum, dihubungkan dengan konteks kehidupan nyata, serta digunakan dalam pembelajaran untuk menemukan makna.

\section{Pembelajaran Sains}

Dari aspek Bahasa sains berasal dari Bahasa Latin scientia yang berarti knowledge atau pengetahuan. Dari ruang lingkup yang luas tersebut, sains telah memberikan pemahaman mengenai alam semesta dan benda-benda yang ada di dalamnya (Clegg, 2019). Dalam pengertian lain, sains merupakan kumpulan teoriteori yang sudah diujicoba yang menjelaskan tentang pola-pola yang teratur ataupun yang tidak teratur diantara fenomena yang dipelajari secara hati-hati (Harré, 1995). Sains secara umum dicirikan dengan pengumpulan dan pengujian informasi dari berbagai sumber secara sistematis yang bertujuan untuk memberikan penjelasan mengenai alam semesta beserta isinya (Martin, 2009; Clegg, 2019). Salah satu cabang dari sains adalah natural science (Bunge, 1998).

Sains atau yang biasa disebut IPA (Hayati, 2017) merupakan ilmu pengetahuan yang berisi tentang fakta, konsep, atau prinsip mengenai gejala alam yang diperoleh melalui proses dan sikap ilmiah (Retno \& Yuhanna, 2016). Sains (IPA) dapat dikelompokkan ke dalam beberapa kelompok ilmu, diantaranya adalah Fisika, Kimia, dan Biologi (Bunge, 1998). Pada umumnya, konsep-konsep dalam sains disusun secara sistematis dari konsep dasar yang sederhana ke konsep tingkat 
lanjut yang kompleks, sehingga untuk dapat menguasai konsep-konsep yang kompleks maka konsep-konsep dasar perlu dikuasai dengan baik (Liniarti, dkk., 2013). Bagi mahasiswa calon guru, penguasaan konsep yang baik dapat membantu mahasiswa untuk membelajarkan sains secara efektif (Kampourakis, 2017; Fauth, dkk. 2019; Lewis, 2019). Dalam pelaksanaannya, pembelajaran sains menekankan pada penerapan pengalaman langsung untuk mencari tahu dan melakukan sesuatu sehingga dapat memberikan pengalaman yang mendalam mengenai alam sekitar (Hayati, 2017).

\section{Metode}

Penelitian ini dilaksanakan di Program Studi PGMI IAIN Manado pada tahun akademik 2018/2019. Penelitian ini merupakan penelitian pengembangan yang mengembangkan buku ajar konsep dasar sains berbasis kontekstual untuk meningkatkan pemahaman konsep sains dasar mahasiswa. Pada penelitian ini, konsep sains dasar yang dimaksud dibatasi pada konsep-konsep dasar Fisika.

Pengembangan buku ajar menggunakan pendekatan research and development ( $R$ and $D$ ) dengan model uji coba one-group pretest-posttest design. Desain penelitian mengadopsi model yang dikembangkan oleh Plomp yang meliputi 4 tahap pengembangan yaitu: 1) tahap investigasi awal; 2) tahap desain; 3) tahap realisasi/konstruksi; dan 4) tahap tes, evaluasi, dan revisi (Rochmad, 2012).

Pada tahap investigasi awal dilakukan analisis kebutuhan, analisis mahasiswa dan analisis kurikulum program studi. Pada tahap desain dilakukan penyusunan garis besar buku ajar dan penyusunan instrumen penilaian. Pada tahap realisasi/konstruksi dihasilkan prototype atau produk awal buku ajar. Pada tahap tes, evaluasi dan revisi dilakukan uji validitas pakar (ahli materi dan ahli media), revisi dan uji coba buku ajar.

Instrumen yang digunakan dalam penelitian ini adalah: 1) lembar angket validasi buku ajar; 2) lembar angket respon mahasiswa; dan 3) lembar penilaian hasil belajar. Angket validasi dan respon mahasiswa menggunakan skala Likert untuk jawaban positif (Tabel 1) dan tes hasil belajar menggunakan tes objektif pilihan ganda yang telah divalidasi.

Tabel 1. Bobot Penilaian

\begin{tabular}{cc}
\hline Bobot & Alternatif Jawaban \\
\hline 5 & Sangat Baik \\
4 & Baik \\
\hline
\end{tabular}




\begin{tabular}{cc}
\hline 3 & Cukup \\
2 & Kurang \\
1 & Sangat Kurang \\
\hline
\end{tabular}

Data angket validasi dianalisis dengan menghitung skor total validator menggunakan persamaan (1) kemudian membandingkan nilai validitas ( $r$ ) dengan nilai kritis ( $r_{\text {kritis }}$ ) yang telah ditentukan (Sugiyono, 2012).

$$
r=\frac{X}{N \cdot n}
$$

dengan $r$ = nilai validitas; $x$ = bobot jawaban responden; $N=$ jumlah skor maksimum; dan $n=$ jumlah responden. Hasil observasi dikatakan valid apabila nilai validitas lebih besar dari nilai kritis $r_{\text {kritis }}=0,30$ (Sugiyono, 2012).

Data angket validitas dan respon mahasiswa dianalisis secara deskriptif dengan mencari presentase sub variabel menggunakan persamaan (2) berikut:

$$
P=\frac{S}{N} \times 100 \%
$$

dengan $P=$ Persentase sub variabel; $S=$ jumlah skor tiap sub variabel; dan $N=$ jumlah skor maksimum. Adapun kriteria penilaian mengacu pada Tabel 2 (Billah, 2019).

Tabel 2. Kriteria Penilaian Presentase Sub Variabel

\begin{tabular}{cc}
\hline Rentang Skor $(\%)$ & Kriteria \\
\hline $75 \leq \mathrm{P} \leq 100$ & Sangat Baik \\
$50 \leq \mathrm{P}<75$ & Baik \\
$25 \leq \mathrm{P}<50$ & Kurang Baik \\
$0 \leq \mathrm{P}<25$ & Tidak Baik \\
\hline
\end{tabular}

Data tes hasil belajar dianalisis dengan mencari nilai gain ternormalisasi ( $n$ gain) menggunakan persamaan (3) dengan kriteria pengelompokan mengacu pada Tabel 3 (Hakke, 1998).

$$
n \text {-gain }=\frac{\text { nilai posttest }- \text { nilai pretest }}{\text { nilai maksimal }- \text { nilai pretest }}
$$

Tabel 3. Kriteria Pengelompokkan n-gain

\begin{tabular}{cc}
\hline$n$-gain $(G)$ & Kriteria \\
\hline$G \geq 0,7$ & Tinggi \\
$0,3 \leq G<0,7$ & Sedang \\
$G<0,3$ & Rendah \\
\hline
\end{tabular}




\section{Hasil}

\section{Tahap Investigasi Awal}

Berdasarkan hasil analisis temuan pada tahap investigasi awal diketahui bahwa: 1) belum tersedianya bahan ajar yang dapat dijadikan sebagai rujukan ataupun sebagai penunjang mata kuliah konsep dasar sains, sumber belajar yang digunakan mahasiswa adalah internet dan buku sekolah menengah; 2) pemahaman konsep-konsep sains dasar mahasiswa tergolong rendah, hal ini ditunjukkan dengan minimnya mahasiswa yang dapat menjelaskan konsep-konsep sains dasar dengan tepat; 3) mahasiswa sulit memahami topik-topik sains, utamanya topik yang terkait dengan fisika; 4) mahasiswa memiliki kemampuan akademik yang heterogen, dimana mahasiswa berasal dari jurusan di sekolah menegah yang beragam; 5) tingginya minat mahasiswa untuk mempelajari sains; dan 6) dibutuhkan buku ajar kontekstual yang dapat meningkatkan pemahaman konsep sains mahasiswa.

\section{Tahap Desain}

Pada tahap ini telah dihasilkan outline buku ajar yang terdiri dari tiga bagian utama yaitu: 1) bagian awal, terdiri dari halaman muka, kata pengantar, dan daftar isi; 2) bagian isi, terdiri dari penjabaran topik-topik fisika yaitu: pengukuran, besaran dan satuan; gerak dan gaya; materi dan perubahannya; cahaya dan alat optik; listrik dan magnet; Bumi dan Tata Surya; dan 3) bagian akhir, terdiri dari glosarium, indeks, dan daftar pustaka.

Instrumen penilaian yang dikembangkan pada tahap ini terdiri dari lembar angket validasi buku ajar, lembar angket respon mahasiswa dan lembar penilaian hasil belajar. Lembar angket validasi buku ajar digunakan untuk mengetahui kelayakan buku ajar dari aspek kelayakan materi (isi, penyajian, kebahasaan, dan kontekstualitas) dan aspek kelayakan media (kegrafikan). Lembar angket respon mahasiswa digunakan untuk mengetahui respon dan tanggapan mahasiswa terhadap kepraktisan penggunaan buku ajar dari aspek tampilan, materi (isi), dan pembelajaran. Lembar penilaian hasil belajar digunakan untuk menguji keefektifan buku ajar yang terdiri dari lembar penilaian awal (pretest) dan lembar penilaian akhir (posttest). 


\section{Tahap Realisasi/konstruksi}

Pada tahap ini dihasilkan prototype atau produk awal buku ajar yang dikembangkan dari outline buku ajar pada tahap desain.

\section{Tahap Tes, Evaluasi, dan Revisi}

Pada tahap ini dihasilkan produk akhir setelah melalui tahap validasi ahli (materi dan media), revisi, dan uji coba buku ajar. Hasil penilaian ahli materi pada aspek kelayakan isi, penyajian, kebahasaan, dan kontekstualitas serta hasil penilaian ahli media pada aspek kelayakan kegrafikan disajikan pada tabel 4.

Tabel 4. Hasil Penilaian Buku Ajar oleh Ahli Materi dan Media

\begin{tabular}{cccc}
\hline Aspek Kelayakan & $r$ & $r_{\text {kritis }}$ & Kategori \\
\hline Isi & 0,87 & 0,30 & Valid \\
Penyajian & 0,83 & 0,30 & Valid \\
Kebahasaan & 0,81 & 0,30 & Valid \\
Kontekstualitas & 0,80 & 0,30 & Valid \\
Kegrafikan & 0,88 & 0,30 & Valid \\
\hline Total & 0,84 & 0,30 & Valid \\
\hline
\end{tabular}

Tahap selanjutnya adalah melakukan revisi buku ajar yang telah divalidasi sesuai dengan saran dan masukan validator. Beberapa saran dan masukan yang diperoleh antara lain: 1) perlu ditambahkan efek warna pada tabel dan bagianbagian penting buku ajar agar terlihat lebih jelas dan menarik; 2) perlu ditambahkan grafik dan gambar nyata yang mendukung penjelasan dalam buku ajar; 3) pembahasan disesuaikan dengan tujuan pembelajaran; 4) perlu ditambahkan beberapa kegiatan pembelajaran yang dapat meningkatkan sikap ilmiah, kreativitas, dan kemampuan berpikir kritis mahasiswa; dan 5) perlu ditambahkan berbagai informasi seperti daftar konstanta, faktor konversi, dan daftar unsur sebagai informasi penunjang buku ajar. Berdasarkan hasil penilaian validator diperoleh kesimpulan secara umum bahwa prototype buku ajar layak diujicobakan dengan perbaikan kecil.

Uji coba kelompok kecil dilakukan pada 10 mahasiswa PGMI semester 4 kelas B untuk mengetahui kepraktisan buku ajar dari aspek tampilan, materi (isi), dan penggunaannya dalam pembelajaran. Hasil respon mahasiswa ditunjukan pada Tabel 5 . 
Tabel 5. Hasil Uji Kelompok Kecil

\begin{tabular}{ccc}
\hline Aspek Penilaian & Rata-rata (\%) & Kategori \\
\hline Tampilan & 88,7 & Sangat Baik \\
Materi (isi) & 90,2 & Sangat Baik \\
Pembelajaran & 92,7 & Sangat Baik \\
\hline Rata-rata & 90,5 & Sangat Baik \\
\hline
\end{tabular}

Uji coba kelompok besar dilakukan pada 31 mahasiswa PGMI semester 4 kelas A menggunakan model one-group pretest-posttest design. Pemahaman konsep sains mahasiswa diukur berdasarkan hasil belajar mahasiswa. Pengukuran awal (pretest) dilakukan di awal kegiatan pembelajaran untuk mengetahui kemampuan awal mahasiswa dan pengukuran akhir (posttest) dilakukan setelah mahasiswa mengikuti 6 kali kegiatan pembelajaran menggunakan buku ajar hasil revisi. Deskripsi data hasil belajar mahasiswa ditunjukkan pada Tabel 6.

Tabel 6. Hasil Belajar Mahasiswa

\begin{tabular}{ccc}
\hline \multirow{2}{*}{ Data } & \multicolumn{2}{c}{ Hasil } \\
\cline { 2 - 3 } & Pretest & Postest \\
\hline Nilai Rata-rata & 72,05 & 90,10 \\
Varians & 8,17 & 10,62 \\
Standar Deviasi & 2,86 & 3,26 \\
Nilai Maksimum & 77,88 & 94,77 \\
Nilai Minimum & 66,94 & 79,38 \\
Rentang & 10,94 & 15,39 \\
N & 31 & 31 \\
\hline
\end{tabular}

Dengan menggunakan persamaan (2), diperoleh nilai gain ternormalisasi $\mathrm{G}=$ 0,67 pada kategori sedang. Hasil uji normalitas, homogenitas dan uji-t ditunjukan pada Tabel 7.

Tabel 7. Ringkasan Analisis Hasil Belajar Mahasiswa

\begin{tabular}{ccc}
\hline Jenis Uji & Hasil $(\alpha=0,05 ;$-tailed $)$ & Kesimpulan \\
\hline Normalitas & $p$-value pretest $=0,681$ & Ho diterima \\
& $p$-value posttest $=0,242$ & \\
Homogenitas & $p$-value $=0,891$ & Ho diterima \\
Paired t-test & $t_{\text {statistik }}=-26,979$ & Ho ditolak \\
& $t_{\text {critical }}=2,043$ & \\
& $p$-value $=0,000$ & \\
\hline
\end{tabular}

\section{Pembahasan}

Hasil yang diperoleh pada tahap investigasi awal merekomendasikan adanya suatu pengembangan bahan ajar konsep dasar sains yang dapat dijadikan sebagai penunjang mata kuliah dan sumber belajar mahasiswa. Bahan ajar yang dikehendaki 
adalah bahan ajar yang mendeskripsikan konsep-konsep sains dasar dengan jelas berdasarkan fenomena-fenomena yang dapat diamati/ditemui dalam kehidupan sehari-hari. Mengingat bahwa input mahasiswa PGMI berasal dari jurusan sekolah menengah yang beragam, maka penjelasan konsep-konsep sains dalam buku ajar hendaknya dapat memfasilitasi kebutuhan belajar yang beragam (Rogayan \& Dollete, 2019). Bahan ajar yang jelas dan mudah dipahami ditujukan untuk meningkatkan pemahaman konsep mahasiswa dan dapat menjadi bekal dalam penerapan pembelajaran di sekolah (Billah, 2019). Bahan ajar yang dikembangkan berbentuk buku ajar. Buku ajar pada perguruan tinggi keguruan berperan penting dalam meningkatkan pemahaman dan kemampuan mahasiswa sebagai calon guru (Yurniawati, 2016). Buku ajar konsep dasar sains yang dikembangkan berbasis kontekstual dan memfokuskan pada topik-topik yang dianggap sulit dipahami oleh mahasiswa, yaitu konsep-konsep terkait benda-benda (fisika). Penggunaan buku ajar berbasis kontekstual berdampak positif terhadap pemahaman konsep mahasiswa (Satriawan \& Rosmiati, 2016).

Pada tahap design dihasilkan rancangan awal buku ajar dan penentuan instrumen penilaian buku ajar. Aspek yang dinilai dari buku ajar adalah kelayakan, kepraktisan, dan keefektifan buku ajar (Satriawan \& Rosmiati, 2016; Astiti, 2019). Pada tahap ini pula ditentukan format dan tata letak (layout) buku ajar, seperti ukuran kertas, spasi, margin, jenis huruf, ukuran huruf, letak gambar, bentuk tabel, serta komponen-komponen lainnya yang diperlukan dalam buku ajar.

Prototype atau produk awal buku ajar yang dihasilkan pada tahap realisasi/kontruksi terdiri dari 6 bab yaitu: pengukuran, besaran dan satuan (Bab I); gerak dan gaya (Bab II); materi dan perubahannya (Bab III); cahaya dan alat optik (Bab IV); listrik dan magnet (Bab V); dan Bumi dan Tata Surya (Bab VI). Pembahasan dalam setiap bab dikembangkan dari konsep-konsep sains dasar yang berbasis kontekstual dan terdiri atas komponen-komponen yang sama, yaitu: pendahuluan, capaian pembelajaran (learning outcome), latihan soal, kata kunci (key word), dan rangkuman. Bagian pendahuluan berisi ruang lingkup materi yang berfungsi untuk memberikan gambaran umum mengenai konsep sains yang sedang dipelajari, capaian pembelajaran merupakan tujuan yang hendak dicapai setelah melalui kegiatan pembelajaran, latihan soal berisi berbagai permasalahan nyata yang dapat diselesaikan secara mandiri atau terbimbing, daftar istilah penting untuk menambah perbendahaaran kata yang terkait sains (Rogayan \& Dollete, 2019) dan rangkuman berisi intisari bab dan konsep-konsep penting yang perlku dikuasai mahasiswa. Di 
bagian akhir setiap bab, disediakan soal-soal uji kompetensi yang berbasis kontekstual dan permasalahan nyata. Jawaban soal-soal uji kompetensi pilihan diletakkan di bagian akhir buku.

Pada tahap selanjutnya, 2 orang ahli materi dan 2 orang ahli media diminta untuk menilai validitas buku ajar yang dikembangkan dari aspek isi, penyajian, kebahasaan, kontekstualitas, dan kegrafikan. Berdasarkan Tabel 4, semua aspek penilaian berada pada kategori valid $(r=0,84)$, karena nilai validitas $(r)$ lebih besar dari $r_{\text {kritis }}(0,30)$ (Sugiyono, 2012). Aspek kegrafikan memiliki penilaian tertinggi $(r=$ $0,88)$, diikuti oleh aspek isi $(r=0,87)$, aspek penyajian $(r=0,83)$, aspek kebahasaan $(r=0,81)$, dan aspek kontekstualitas $(r=0,80)$. Berdasarkan hasil penilaian validator, buku ajar yang dikembangkan memenuhi aspek kelayakan isi, penyajian, kebahasaan, kontekstualitas, dan kegrafikan.

Validator memberikan respon yang baik terhadap pengembangan buku ajar yang dikembangkan dan berharap dapat memberikan efek positif terhadap pemahaman konsep sains mahasiswa. Saran dan masukan validator digunakan untuk perbaikan buku ajar. Salah satu revisi yang dilakukan adalah menambahkan bab tambahan (Bab VII) yang berisi berbagai aktifitas pembelajaran yang dapat meningkatkan sikap ilmiah, kreativitas, dan kemampuan berpikir kritis mahasiswa. Kegiatan pembelajaran tersebut dirangkum dalam kegiatan eksperimen pilihan yang dapat menunjang konsep-konsep penting dalam buku ajar serta dapat dilakukan secara mandiri oleh mahasiswa. Selain itu, untuk mefasilitasi mahasiswa dalam belajar, di bagian akhir dilengkapi dengan bagian tambahan yang berisi kunci jawaban soal-soal pilihan, alfabet Yunani, faktor konversi satuan, konstanta numerik, dan tabel periodik unsur. Secara umum revisi yang dilakukan ditujukan untuk meningkatkan perhatian dan minat belajar mahasiswa melalui penggunaan buku ajar. Dampak positif bahan ajar dapat dilihat dari adanya peningkatan rasa ingin tahu, minat, dan perhatian penggunanya terhadap materi pelajaran (Tomlinson, 1998).

Hasil uji coba kelompok kecil digunakan untuk mengetahui kepraktisan buku ajar yang dikembangkan. Tujuan lain dari pengujian buku ajar adalah untuk mengidentifikasi kelemahan-kelemahan dalam buku ajar (Heinich, dkk., dalam Belawati, dkk., 2003). Responden memberikan penilaian terhadap buku ajar dari aspek tampilan, materi (isi), dan pembelajaran. Berdasarkan Tabel 5, respon mahasiswa menunjukkan hasil yang sangat baik ( $P_{\text {rata-rata }}=90,5 \%$ ). Aspek pembelajaran memperoleh nilai tertinggi (92\%), diikuti oleh aspek materi (90,2\%), 
dan aspek tampilan (88,7\%). Semua aspek penilaian berada pada kategori sangat baik ( $\geq 75 \%$ ). Responden mengangap bahwa buku ajar yang dikembangkan sesuai dengan kebutuhan belajarnya, memiliki tampilan yang menarik, dan mudah dipahami karena penjelasannya dilengkapi dengan contoh dalam kehidupan seharihari. Bahan ajar kontekstual memberikan peluang yang besar untuk menemukan konsep-konsep penting melalui fenomena-fenomena yang dapat dijumpai dalam kehidupan sehari-hari (Astiti, 2019). Selain itu, mahasiswa lebih tertarik untuk mempelajari materi yang diberikan jika contoh-contoh yang disajikan merupakan permasalahan yang pernah dihadapi (Satriawan \& Rosmiati, 2016). Berdasarkan hasil respon mahasiswa, buku ajar yang dikembangkan memenuhi aspek kepraktisan.

Pada tahap selanjutnya, buku ajar diujicobakan pada kelompok besar menggunakan model one-group pretest-posttest design. Uji coba ini diperlukan untuk mengetahui efektifitas buku ajar dalam meningkatkan pemahaman konsep mahasiswa pada topik-topik sains (Rogayan \& Dollete, 2019). Pemahaman konsep sains mahasiswa diukur menggunakan tes hasil belajar yang kemudian dibandingkan dengan kemampuan awal mahasiswa. Hal tersebut dilakukan untuk mengetahui perbandingan sebelum dan setelah menggunakan produk (buku ajar) yang dikembangkan (Sugiyono, 2013). Berdasarkan Tabel 6, diperoleh hasil bahwa terdapat peningkatan hasil belajar rata-rata sebesar $18,05 \%$, dari nilai rata-rata 72,05 $(\mathrm{SD}=2,86)$ pada pretest menjadi 90,10 $(\mathrm{SD}=3,26)$ pada posttest. Nilai gain ternormalisasi (n-gain) yang diperoleh sebesar 0,67 pada kategori sedang.

Pengujian normalitas data dilakukan menggunakan uji Kolmogorov-Smirnov dengan bantuan Statistical Product and Service Solution (SPSS) versi 24.0. Data dikatakan berdistribusi normal jika nilai probabilitas ( $p$-value) lebih besar atau sama dengan tingkat signifikansi $\alpha$ (Gio \& Rosmaini, 2016). Berdasarkan Tabel 7, diperoleh nilai $p$-value untuk pretest dan posttest berturut-turut adalah 0,681 dan 0,242. Karena kedua nilai $p$-value lebih besar dari tingkat signifikansi $(\alpha=0,05)$ maka Ho diterima, artinya kedua data tersebut berdistribusi normal.

Pengujian homogenitas data dilakukan menggunakan uji Levene dengan bantuan SPSS versi 24.0. Asumsi kesmaan varians terpenuhi jika nilai probabilitas ( $p$ value) lebih besar atau sama dengan tingkat signifikansi $\alpha$ (Gio \& Rosmaini, 2016). Berdasarkan Tabel 7, diperoleh nilai $p$-value sebesar 0,891. Karena nilai $p$-value lebih besar dari tingkat signifikansi $(\alpha=0,05)$ maka Ho diterima, artinya tidak terdapat perebedaan varians diantara kedua kelompok data (asumsi homogenitas terpenuhi). 
Uji-t sampel berpasangan (paired t-test) dilakukan untuk mengetahui ada tidaknya pengaruh yang signifikan secara statistika pada penggunaan buku ajar dalam pembelajaran sains terhadap pemahaman konsep sains dasar mahasiswa. Uji-t dilakukan dengan bantuan SPSS versi 24.0. Pengambilan keputusan terhadap hipotesis dilakukan dengan membandingkan nilai statitik dari uji-t $\left(t_{\text {statistik }}\right)$ terhadap nilai kritis berdasarkan tabel distribusi $t$ ( $\left.t_{\text {kritis }}\right)$. Pada uji dua pihak, jika nilai $\left|t_{\text {statistik }}\right|>$ $\left|t_{\text {kritis }}\right|$ maka Ho ditolak (Gio \& Rosmaini, 2016). Berdasarkan Tabel 7, diperoleh nilai $\left|t_{\text {statistik }}\right|$ sebesar 26,979 ( $p$-value $\left.=0,000\right)$ dan nilai $\left|t_{\text {kritis }}\right|$ sebesar 2,043 $(d f=29 ; a=$ $0,05)$ untuk uji dua pihak. Karena nilai $\left|t_{\text {statistik }}\right|$ lebih besar dari nilai $\left|t_{\text {kritis }}\right|(26,979>$ 2,043) maka Ho ditolak, sehingga dapat disimpulkan bahwa penggunaan buku ajar berpengaruh secara signifikan terhadap pemahaman konsep sains dasar mahasiswa.

Hasil yang diperoleh pada penelitian ini sejalan dengan hasil penelitian sebelumnya (Satriawan \& Rosmiati, 2016). Namun demikian, disarankan penggunaan bahan ajar lainnya untuk menunjang pembelajaran sains sehingga mahasiswa memiliki pemahaman konsep sains yang lebih baik (Rogayan \& Dollete, 2019). Studi lanjutan diperlukan untuk mengukur koherensi buku ajar terhadap kompetensi yang ingin dicapai pada kurikulum program studi. Selain itu, pendekatan kualitatif dapat digunakan untuk menganalisis kepraktisan buku ajar secara lebih mendalam.

\section{Simpulan}

Produk buku ajar konsep dasar sains berbasis kontekstual yang dikembangkan untuk mahasiswa Program Studi Pendidikan Guru Madrasah Ibtidaiyah memenuhi syarat dan layak digunakan sebagai buku ajar. Berdasarkan penilaian ahli materi dan ahli media, buku ajar memenuhi aspek kelayakan isi, penyajian, kebahasaan, kontekstualitas dan kegrafikan. Berdasarkan hasil respon mahasiswa pada uji coba kelompok kecil, buku ajar praktis digunakan. Berdasarkan hasil uji coba kelompok besar, penggunaan buku ajar dalam pembelajaran dapat meningkatkan pemahaman konsep sains dasar mahasiswa. 


\section{Referensi}

Akbar, S. (2013). Instrumen Perangkat Pembelajaran. Bandung: PT. Remaja Rosdakarya.

Astiti, K. A. (2019). Pengembangan Bahan Ajar Fisika SMA berbasis Kontekstual pada Materi Suhu dan Kalor. Jurnal Pembelajaran Sains, 3(1), 29-34. http://dx.doi.org/10.17977/um033v3i1p29-\%2034.

Aydin, A., \& Aytekin, C. (2018). Teaching Materials Development and Meeting The Needs of The Subject: A Sample Application. International Education Studies, 11(8), 27-38. https://doi.org/10.5539/ies.v11n8p27.

Billah, A. (2019). Pengembangan Bahan Ajar Konsep Dasar Fisika untuk Mahasiswa Pendidikan Guru Madrasah Ibtidaiyah. Journal of Teaching and Learning Physic, 4(2), 35-44. https://doi.org/10.15575/jotalp.v4i2.5582.

Belawati, T., Padmo, D., Purwanto, dan Sadjati, I. M. (2003). Pengembangan Bahan Ajar. Jakarta: Universitas Terbuka.

BSNP, (2006). Panduan Penyusunan Kurikulum Tingkat Satuan Pendidikan Jenjang Pendidikan Dasar dan Menengah. Jakarta: Badan Standarisasi Nasional Pendidikan.

Bunge, M. (1998). Philosophy of Science: Volume 1, From Problem to Theory (Revised Edition). New York: Routledge.

Clegg, B. (2007). Getting Science. New York: Routledge.

Clegg, B. (2019). Scientifica Historica: How The World's Great Science Books Chart the History of Knowledge. UK: Ivy Press.

Fauth, B., Decristan, J., Decker, A-. T., Büttner, G., Hardy, I., Klieme, E., \& Kunter, M. (2019). The Effects of Teacher Competence on Student Outcomes in Elementary Science Education: The Mediating Role of Teaching Quality. Teaching and Teacher Education, 86, 14. https://doi.org/10.1016/j.tate.2019.102882.

Gio, P. G., \& Rosmaini, E. (2016). Belajar Olah Data dengan SPSS, Minitab, R, Microsoft Excel, EViews, Lisrel, AMOS, dan SmartPLS. Medan: USU Press.

Grover, R. B. (2019). The Relationship between Science and Technology and Evolution in Methods of Knowledge Production. Indian Journal of History of Science, 54(1), 50-68. https://doi.org/10.16943/ijhs/2019/v54i1/49597.

Hake, R. R. (1998). Interactive-enggagment versus Traditional Methods: A Sixthousand-student Survey of Mechanics Test Data for Introductory Physics Courses. American Journal of Physics, 66(1), 64-74. https://doi.org/10.1119/1.18809. 
Harré, R. (1995). The Philosophies of Science, an Introductory Survey. London: The Oxford University Press.

Hayati, D. K. (2017). Pengembangan Buku Ajar Konsep dasar IPA untuk Meningkatkan Keterampilan Proses Sains Mahasiswa. Jurnal Gentala Pendidikan Dasar. 2(1), 151-167. https://doi.org/10.22437/gentala.v2i1.6824.

Insih, W., Zuhdan, K. P., Pratiwi, P. A., \& Ikhlasul, A. N. (2009). Peningkatan Penguasaan Konsep-konsep dasar Sains Calon Guru SD Melalui Perangkat Perkuliahan Berbasis Struktur Pembelajaran SEQIP (Science Education, Quality Improvement Project). Seminar Nasional Penelitian, Pendidikan dan Penerapan MIPA 2009. http://eprints.uny.ac.id/id/eprint/12326.

Irawati, H., \& Saifuddin, M. F. (2018). Analisis Kebutuhan Pengembangan Bahan Ajar Mata Kuliah Pengantar Profesi Guru Biologi di Pendidikan Biologi Universitas Ahmad Dahlan Yogyakarta. Bio-Pedagogi: Jurnal Pembelajaran Biologi, 7(2), 9699. https://jurnal.uns.ac.id/pdg/article/view/27636/19084.

Johnson, E. B. (2007). Contextual Teaching Learning. Bandung: MLC.

Kampourakis, K. (2017). Science Teaching in University Science Department: The "Missing Link" in Science Education?. Science \& Education, 26, 201-203. https://doi.org/10.1007/s11191-017-9903-5.

Lestari, I. (2013). Pengembangan Bahan Ajar berbasis Kompetensi. Jakarta: PT. Indeks.

Lewis, A. D. (2019). Practice What You Teach: How Experiencing Elementary Science Teaching Practices Helps Prepare Teacher Candidates. Teaching and Teacher Education, 86, 1-10. https://doi.org/10.1016/j.tate.2019.102886.

Liniarti, Kadaritna, N., Rosilawati, I., \& Rudibyani, R. B. (2013). Peningkatan Keterampilan Menyimpulkan dan Mengkomunikasikan Siswa melalui Inquiry Terbimbing. Jurnal Pendidikan dan Pembelajaran Kimia, 2(3), 1-13. http://jurnal.fkip.unila.ac.id/index.php/JPK/article/view/3036/1916.

LKPP Unhas. (2015). Bahan Ajar, Buku Ajar, Modul, dan Panduan Praktik. Makassar: Lembaga Kajian dan Pengembangan Pendidikan Uiversitas Hasanuddin.

Majid, A. (2017). Perencanaan Pembelajaran: Mengembangkan Standar Kompetensi Guru. Bandung: PT. Remaja Rosdakarya.

Mardiana, D., \& Cahyani, R. (2018). The Development of Basic Natural Science Learning Materials to Improve Students' Competence. Journal of Physics: Conference Series, 1028(012206), 1-8. https://doi.org/10.1088/1742$6596 / 1028 / 1 / 012206$.

Martin, D. J. (2009). Elementary Science Method: A Conctructivist Approach (5 $5^{\text {th }}$ ed.). USA: Wadsworth Cengage Learning. 
Maulina, D., Sumitro, S. B., Amin, M., \& Lestari, S. R. (2016). Kajian Kebutuhan Bahan Ajar Mata Kuliah Biologi Sel di Universitas Lampung. Seminar Nasional Pendidikan dan Saintek 2016. 942-945.

Pradana, F. A., Suyatna, A., Ertikanto, C., \& Herlina, K. (2019). The Development of an Electronic Book on Quantum Phenomena to Enhance Higher-Order Thinking Skills of the Students. Journal of Physics: Conference Series, 1155(012012), 1-7. https://doi.org/10.1088/1742-6596/1155/1/012012.

Prastowo, A. (2015). Panduan Kreatif Membuat Bahan Ajar Inovatif. Yogyakarta: Diva Press.

Retno, R. S., \& Yuhanna, W. L. (2016). Pembelajaran Konsep Dasar IPA dengan Scientific Inquiry untuk Meningkatkan Kemampuan Berpikir, Bekerja, dan Bersikap Ilmiah pada Mahasiswa. Jurnal Pendidikan Biologi Indonesia, 2(1), 1-9. https://doi.org/10.22219/jpbi.v2i1.2703.

Rochmad. (2012). Desain Model Pengembangan Perangkat Pembelajaran Matematika. Kreano: Jurnal Matematika Kreatif-Inovatif, 3(1), 59-72. https://doi.org/10.15294/kreano.v3i1.2613.

Rogayan, D. V. Jr., \& Dollete, L. F. (2019). Development and Validation of Physical Science Workbook for Senior High School. Science Education International, 30(4), 284-290. https://doi.org/10.33828/sei.v30.i4.5.

Sadler, P. M., Sonnert, G., Coyle, H. P., Cook-Smith, N., \& Miller, J. L. (2013). The Influence of Teachers' Knowledge on Student Learning in Middle School Physical Science Classrooms. American Educational Research Journal, 50(5), 1020-1049. https://doi.org/10.3102/0002831213477680.

Satriawan, M., \& Rosmiati (2016). Pengembangan Bahan AJar Fisika berbasis Kontekstual dengan Mengintegrasikan Kearifan Lokal untuk Meningkatkan Pemahaman Konsep Fisika pada Mahasiswa. Jurnal Penelitian Pendidikan Sains, 6(1), 1212-1217. https://journal.unesa.ac.id/index.php/jpps/article/view/540.

Silaban, B. (2014). Hubungan antara Penguasaan Konsep Fisika dan Kreativitas dengan Kemampuan Memecahkan Masalah pada Materi Pokok Listrik Statis. Jurnal Penelitian Bidang Pendidikan, 20(1), 65-75. htps://doi.org/10.24114/jpbp.v20i1.3072.

Su'udiah, F., Degeng, I. N. S., Kuswandi, D. (2016). Pengembangan Buku Teks Tematik berbasis Kontekstual. Jurnal Pendidikan: Teori, Penelitian, dan Pengembangan, 1(9), 1744-1748. http://dx.doi.org/10.17977/jp.v1ig.6743.

Sugiyono. (2012). Memahami Penelitian Kualitatif. Bandung: Alfabeta.

Sugiyono. (2013). Metode Penelitian Pendidikan. Bandung: Alfabeta. 
Tomlinson, B. (1998). Material Developments in Language Teaching. Cambridge: Cambridge University Press.

Widayanti, Abdurrahman, \& Suyatna, A. (2019). Future Physic Learning Materials based on STEM Education: Analysis of Teachers and Students Perceptions. Journal of Physics: Conference Series, 1155(012021), 1-9. http://dx.doi.org/10.1088/1742-6596/1155/1/012021.

Wulandari, A., Dasna, I. W., \& Wonorahardjo, S. (2019). Effectiveness of Contextualbased Instructional Materials of Elements of Group 15 For Inorganic Chemistry. Jurnal Pendidikan dan Pembelajaran, 26(1), 28-35. http://journal2.um.ac.id/index.php/jpp/article/view/10002.

Yurniawati, (2016). The Development of Learning Materials base on Geogebra for Prospective Teacher. International Conference on Education 2016, 985-990. 